\title{
PETUNJUK ALQURAN TENTANG BELAJAR DAN PEMBELAJARAN
}

\author{
Munirah \\ Fakultas Tarbiyah dan Keguruan UIN Alauddin Makassar \\ Kampus II: Jalan Sultan Alauddin Nomor 36 Samata-Gowa \\ Email: iramunirah74@gmail.com
}

\begin{abstract}
Abstrak:
Alquran, sebagai landasan pendidikan Islam, memiliki kedudukan sebagai qat'i al-dalalah. Sedangkan hadis, ada yang qat'i al-dalalah dan ada yang zanni al-dalalah. Karena demikian halnya, maka yang harus dijadikan landasan utama atau pertama dalam pendidikan Islam adalah Alquran, dimana di dalamnya banyak ditemukan ayat-ayat yang berkenaan dengan pentingnya belajar dan pembelajaran serta Alquran memuat metode-metode untuk memudahkan umat manusia memahami ciptaan Allah swt. Ini merupakan esensi dari pendidikan Islam. Tulisan ini membahas petunjuk Alquran tentang belajar dan pembelajaran serta metode Alquran dalam belajar dan pembelajaran dengan menggunakan metode dialog/ diskusi. Ini sangat menarik untuk dikaji karena Alquran rupanya telah mengajarkan beberapa metode yang sangat moderen jauh sebelum dikembangkan oleh para ahli pendidikan dan psikologi seperti metode kisah, metode perumpamaan, metode keteladanan, metode praktek dan pengulangan, metode ibrah dan mau'izah, serta metode targhib dan tarhib.
\end{abstract}

\begin{abstract}
:
As the foundation of Islamic education, then the Quran has ranked as qath'i dalalah. while al-Hadith some are qath'i dalalah and some are zanni dalalah. Because of the case, so that Quran should be the main or first base in education, in which there are many verses found explaining about the importance of learning and teaching. The Quran also contains methods to facilitate mankind to understand the creation of God which is an essence of islamic education. This article discusses about the direction of Quran about learning and teaching, methods in Quran in learning and teaching and dialogues/discussion method. It is very interesting to be investigated because Quran has taught several very modern methods before educationist and psychologists developing it such as story method, exemplary method, practice and repetition method, 'ibrah and mau'idzah method, targhib and tarhib method.
\end{abstract}

Kata kunci:

Petunjuk Alquran, Belajar, Pembelajaran

MANUSIA merupakan makhluk Allah yang memiliki kelebihan dan keistimewaan dibanding makhluk Allah yang lain. ${ }^{1}$ Manusia diberikan potensi berupa akal untuk berpikir. Dengan potensi itu manusia diangkat sebagai khalifah Allah di muka bumi ini. ${ }^{2}$ Manusia dengan potensi akalnya dapat melakukan sebagai eksperimen, menganalisis, merenungkan, menunjukkan alasan-alasan, membuktikan sesuatu, menggolong-golongkan, membandingkan, menarik kesimpulan, dan membahas secara realitas $^{3}$ terhadap permasalahan yang mengharuskan ia berpikir. Dalam proses berpikir 
atau bernalar merupakan bentuk kegiatan manusia untuk mendapatkan pengetahuan dan ini dapat dikatakan sebagai bentuk proses belajar dan pembelajaran.

Proses belajar dan pembelajaran sebuah keharusan bagi manusia dalam kehidupan. Berbagai fenomena yang terjadi di alam raya ini akan terungkap kepermukaan bila dilakukan dengan jalan belajar. Belajar dalam pengertian ini tentunya dalam pengertian yang luas, pembacaan terhadap fenomena alam dan realitas sosial masyarakat akan memberikan implikasi positif dengan lahirnya berbagai penemuan dalam bentuk ilmu pengetahuan berupa ilmu alam, ilmu sosial, ilmu humaniora, ilmu jiwa dan ilmu kesehatan dll. Kesemuanya ini merupakan hasil kegiatan belajar dan pembelajaran yang dilakukan oleh manusia itu sendiri. Manusia semakin menyadari dirinya untuk belajar, semakin banyak pengetahuan yang dimilkinya. Potensi yang ada pada diri manusia jika dikembangkan dengan belajar akan melahirkan peradaban besar bagi kemaslahatan pada manusia itu sendiri.

Belajar dan pembelajaran sudah berjalan pada zaman Nabi Muhammad saw., dengan kata lain bahwa pendidikan Islam sudah ada sejak zaman Nabi Muhammad saw. Proses pendidikan Islam berjalan seiring dengan usaha Nabi saw. mengembangkan agama. Oleh karena itu, pendidikan Islam merupakan kebutuhan pokok bagi setiap muslim dan pada prinsipnya kajian atas konsep pendidikan Islam akan membawa pada konsep syariat agama karena bagaimanapun, agamalah yang harus menjadi akar pendidikan.

Dari segi sifat dan coraknya, ilmu pendidikan Islam dapat dibagi menjadi empat bagian. Pertama, ilmu pendidikan Islam yang bercorak normatif, yaitu kajian ilmu pendidikan yang berbasis pada ajaran yang terkandung dalam Alquran dan hadis. Kedua, ilmu pendidikan yang bercorak filosofis, yaitu kajian pendidikan yang berbasis pada penalaran mendalam yang dilakukan para sarjana muslim. Ketiga, ilmu pendidikan Islam yang bercorak historis empirirs, yaitu kajian pendiddikan Islam yang bertumpu pada informasi yang tercatat dalam sejarah dan dapat dilacak akar-akarnya, dan keempat ilmu pendidikan Islam yang bercorak implikatif, yakni kajian pendidikan Islam yang bertumpuh pada sistem dan cara penerapannya. ${ }^{4}$

Keempat sifat dan corak ilmu pendidikan Islam tersebut di atas sangat penting untuk dikaji secara bersamaan, namun yang harus dijadikan fokus utama adalah sifat dan corak normatifnya yang berumpu pada Alquran dan hadis, karena ia merupakan landasan utama dalam pendidikan Islam. ${ }^{5}$ Bila pendidikan tidak berlandaskan pada Alquran dan hadis, bukan pendidikan Islam namanya.

Sebagai landasan pendidikan Islam, Alquran memiliki kedudukan sebagai qat'i al-dalalah. Sedangkan hadis, ada yang qat'i al-dalalah dan ada yang zanni al-dalaalah. Karena demikian halnya, yang harus dijadikan landasan utama atau pertama dalam pendidikan Islam adalah Alquran, dimana di dalamnya banyak ditemukan ayat-ayat yang berkenaan dengan pentingnya belajar dan pembelajaran serta Alquran memuat metode-metode untuk memudahkan umat manusia memahami ciptaan Allah swt. Ini merupakan esensi dari pendidikan Islam. 
Dengan merujuk pada uraian latar belakang di atas, maka diperlukan upaya penelusuran terhadap ayat-ayat Alquran yang berkenaan dengan pentingnya belajar dan pembelajaran, serta metode yang digunakan Alquran dalam proses belajar dan pembelajaran. Untuk itu permasalahan yang dijadikan obyek pembahasan dalam tulisan ini adalah bagaimana petunjuk Alquran tentang belajar dan pembelajaran dan bagaimana metode Alquran dalam proses belajar dan pembelajaran.

\section{PETUNJUK ALQURAN TENTANG BELAJAR DAN PEMBELAJARAN}

Istilah belajar adalah sebagai upaya perubahan tingkah laku dengan serangkaian kegiatan seperti membaca, mendengar, mengamati, meniru dan lain sebagainya. Dengan kata lain, belajar sebagai kegiatan psikofisik untuk menuju perkembangan pribadi seutuhnya. Adapun yang dimaksud dengan pembelajaran adalah usaha kondusif agar langsung berlangsung kegiatan belajar dan menyangkut transfer of knowled$g e$, serta mendidik. ${ }^{6}$ Dengan demikian, belajar dan pembelajaran adalah dua kegiatan yang tidak dapat dipisahkan, dimana keduanya merupakan interaksi edukatif yang memiliki norma-norma.

Istilah belajar dan pembelajaran dapat diartikan sebagai konsep taklim dan Islam. Taklim berasal dari kata 'allama, yuallimu, ta'liman. Istilah taklim pada umumnya berkonotasi dengan tarbiyah, tadris, dan ta' dib, 7 meskipun bila ditelusuri secara mendalam maka istilah tersebut akan terjadi perbedaan makna. Perintah untuk taklim banyak dalil yang menjelaskannya, baik dari sumber Alquran maupun hadis Nabi Muhammad saw. Misalnya hal-hal yang berkaitan dengan orang-orang yang menuntut ilmu pengetahuan, perbedaan orang yang belajar dengan yang tidak, atau melalui hadis-hadis Nabi Muhammad saw., pentingnya menuntun ilmu pengetahuan sekalipun sampai ke negeri Cina.

Khusus dalam pendidikan Islam, Alquran menjadi sumber normatifnya. Berdasarkan hal ini, maka dapat dipahami bahwa belajar dan pembelajaran akan ditemukan dalil-dalilnya dari Alquran yang berkenaan dengan petunjuk Alquran tentang pentingnya belajar dan pembelajaran:

Perintah belajar dan pembelajaran dikemukakan dalam QS al-'Alaq/96: 1-5

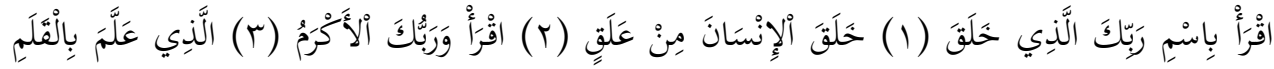

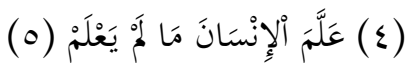

Bacalah dengan (menyebut) nama Tuhan Yang menciptakan, Dia telah menciptakan manusia dari segumpal darah. Bacalah, dan Tuhanmulah Yang Maha Pemurah, Yang mengajar (manusia) dengan perantaraan kalam. Dan mengajarkan kepada manusia apa yang tidak diketahuinya. ${ }^{8}$

Ayat di atas, mengandung pesan ontologis tentang belajar dan pembelajaran. Dalam hal ini, nabi Muhammad Saw, yang ummi (buta huruf aksara) melalui ayat tersebut. Ia diperintahkan untuk belajar membaca. Yang dibaca itu obyeknya bermacam-macam, dan ayat-ayat yang tertulis (ayat al-qur'aniyah), dan ada pula ayatayat yang tidak tertulis (ayat al-kawniyah). 
Hasil yang ditimbulkan dengan usaha belajar membaca ayat-ayat qur'aniyah, dapat menghasilkan ilmu agama seperti fikih, tauhid, akhlak dan semacamnya. Sedangkan hasil yang ditimbulkan dengan usaha membaca ayat-ayat kawniyah, dapat menghasilkan sains seperti fisika, biologi, kimia, astronomi, dan semacamnya. Dapat dirumuskan bahwa ilmu yang bersumber dari ayat-ayat qur'aniyah dan kawniyah, harus diperoleh melalui proses belajar membaca.

Timbul pertanyaan, mengapa kata iqra' atau perintah membaca sederatan ayat di atas terulang dua kali yakni pada ayat 1 dan 3. Jawabannya antara lain menurut $M$. Quraish Shihab bahwa perintah pertama dimaksudkan sebagai perintah belajar tentang sesuatu yang belum diketahui, sedang yang kedua perintah untuk mengajarkan ilmu kepada orang lain. ${ }^{9}$ Ini mengindikasikan bahwa dalam proses belajar dan pembelajaran dituntut adanya usaha yang maksimal dan memfungsikan segala komponen berupa alat-alat potensial yang ada pada diri manusia. Setelah ilmu tersebut diperoleh melalui pembelajaran, maka amanat selanjutnya adalah mengajarkan ilmu tersebut, dengan cara tetap memfungsikan segala potensi tersebut.

QS An-Nahl (16): 78 berbicara tentang komponen pada diri manusia yang harus digunakan dalam kegiatan belajar dan pembelajaran:

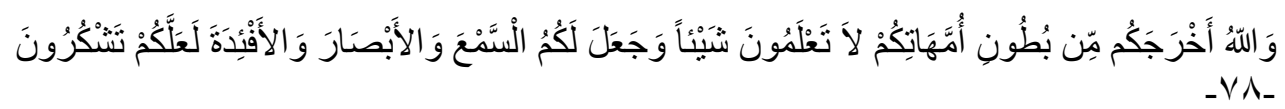

Dan Allah mengeluarkan kamu dari perut ibumu dalam keadaan tidak mengetahui sesuatupun, dan Dia memberi kamu pendengaran, penglihatan dan hati, agar kamu bersyukur. ${ }^{10}$

Ayat di atas mengisyaratkan adanya tiga komponen yang terlibat dalam teori pembelajaran, yaitu: al-sam'a, al-bashar dan al-fu'ad. Secara leksikal, kata al-sam'a berarti telinga yang fungsinya menangkap suara, memahami pembicaraan, dan selainnya. Penyebutan al-sama dalam Alquran seringkali dihubungkan dengan penglihatan dan qalbu, yang menunjukkan adanya saling melengkapi antara berbagai alat itu dalam kegiatan belajar dan mengajar. Hal ini dapat dilihat secara jelas dalam QS AlIsra (17): 36; QS al-Mu' minun (23): 78; QS as-Saj' dah (32): 9 dan QS al-Mulk (67): 23.

Mengenai kata al-bashar yang berarti mengetahui atau melihat sesuatu, diidentikkan pemaknaannya dengan term $r a^{\prime} a$ yakni melihat. Banyak ayat Alquran yang menyeru manusia untuk melihat dan merenungkan apa yang dilihatnya. Hal ini dapat ditemui misalnya dalam QS al-A'raf (7): 185; QS Yunus (10): 101; QS al-Sajadah (32): 27 dan selainnya. Sedangkan al-fu'ad adalah nama lain dari kata qalbu. Al-fu'ad atau al-qalb merupakan pusat penalaran yang harus difungsikan dalam kegiatan belajar dan mengajar. Ayat-ayat yang menyebutkan kata tersebut misalnya; QS al-Haj (22): 46; QS al-Syuara (26): 192-194; dan QS Muhammad (47): 24.

Kaitannya dengan uraian di atas, Dawan Rahardjo menyatakan bahwa agaknya pendengaran, penglihatan dan kalbu (al-fuad) adalah alat untuk memperoleh ilmu dalam kegiatan belajar, dan dapat dikembangkan dalam kegiatan pengajaran. ${ }^{11}$ Ketiga komponen telah disebutkan, yakni al-sama, al-bashar, dan al-fuad merupakan alat 
potensial yang dimiliki manusia untuk dipergunakan dalam kegiatan belajar dan pembelajaran.

Kaitan antara ketiga komponen tersebut adalah bahwa pendengaran bertugas memelihara ilmu pengetahuan yang telah ditemukan dari hasil belajar dan pembelajaran, penglihatan bertugas mengembangkan ilmu pengetahuan dan menambahkan hasil penelitian dengan mengadakan pengkajian terhadapnya. Hati bertugas membersihkan ilmu pengetahuan dari segala sifat yang jelek. Yang terakhir ini, berkaitan dengan teori belajar dan pembelajaran dalam aspek aqidah dan akhlak.

QS Luqman (31): 17-19 tentang pemantapan aqidah dan akhlak dalam belajar dan pembelajaran:

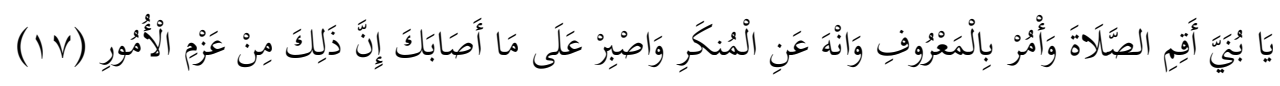

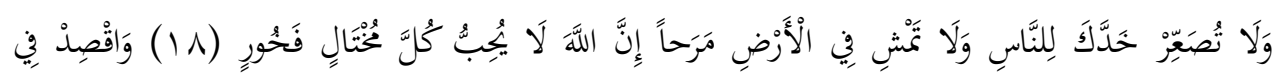

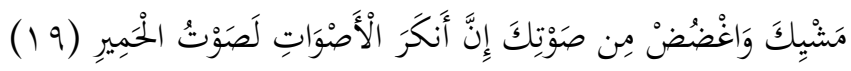

Hai anakku, dirikanlah shalat dan suruhlah (manusia) mengerjakan yang baik dan cegahlah (mereka) dari perbuatan yang mungkar dan bersabarlah terhadap apa yang menimpa kamu. Sesungguhnya yang demikian itu termasuk hal-hal yang diwajibkan (oleh Allah). Dan janganlah kamu memalingkan mukamu dari manusia (karena sombong) dan janganlah kamu berjalan di muka bumi dengan angkuh. Sesungguhnya Allah tidak menyukai orang-orang sombong lagi membanggakan diri. Dan sederhanalah dalam berjalan dan lunakkanlah suaramu. Sesungguhnya seburuk-buruk suara ialah suara keledai. ${ }^{12}$

Para pakar pendidikan sepakat bahwa QS Luqman (31): 12-19 adalah ayat berbicara tentang pendidikan. Dalam ayat 12-16 berbicara tentang pendidikan aqidah yang dimulai dengan pengajaran tentang keEsaan Allah. Kemudian pada ayat 17 yang dikutip di atas, berkenaan dengan pengajaran shalat ${ }^{13}$ disertai anjuran untuk menyuruh kepada yang ma'ruf dan mencegah kemungkaran. Dengan ayat-ayat tersebut, dipahami bahwa usaha yang pertama kali harus dilakukan dan diajarkan kepada peserta didik dalam proses pendidikan setelah masalah aqidah yang meliputi ibadah, adalah masalah akhlak, yakni sopan santun berinteraksi dengan sesama manusia.

Luqman mengajar anaknya dengan bentuk nasihat. Ia berkata: wahai anakku, janganlah engkau berkeras memalingkan pipimu yakni mukamu dari manusia siapapun dia, dan bila engkau melangkah janganlah engkau angkuh, tetapi berjalanlah dengan lembut dan penuh wibawa. Bersikap sederhanalah dalam langkahmu, jangan tergesa-gesa. Lunakkanlah suaramu sehinnga tidak terdengar kasar seperti keledai, sesungguhnya seburuk-buruk suara ialah suara keledai karena awalnya siulan yang tidak menarik dan akhirnya terikan nafas yang buruk.

Dapat dirumuskan bahwa ayat 18 di atas mengandung nilai-nilai pendidikan dalam aspek akhlak, yakni larangan bersikap sombong, karena kesombongan dan keangkuhan adalah salah satu sikap jelek yang dibenci Allah swt. Selanjutnya, pada ayat 19 terdapat perintah untuk bersikap sederhana dalam berbicara dan bertindak, karena kesederhanaan adalah akhlak yang baik dan merupakan salah satu ciri orang 
yang beriman, sebagaimana Rasulullah Saw., menjadi teladan utama dan paling mulia akhlaknya yang ditegaskan oleh Allah swt., dalam QS al-Ahzab (33): 21 dan QS al-Qalam (68).

Tujuan pembentukan penanaman aqidah dan pembentukan akhlak al-mahmudah merupakan bagian yang sangat urgen dalam pendidikan Islam. Sekaitan dengan ini, al-Saybani menyatakan antara lain bahwa tujuan umum pendidikan Islam adalah membantu pembentukan akhlak yang mulia. ${ }^{14}$ Karena itu, internalisasi nilai-nilai pendidikan Islam dalam proses pembelajaran terutama dalam aspek aqidah, ibadah, dan akhlak menjadi sesuatu hal yang mendasar dan sekaligus merupakan kewajiban bagi setiap muslim.

QS al-Nahl (16): 125 kewajiban tentang belajar dan pembelajaran

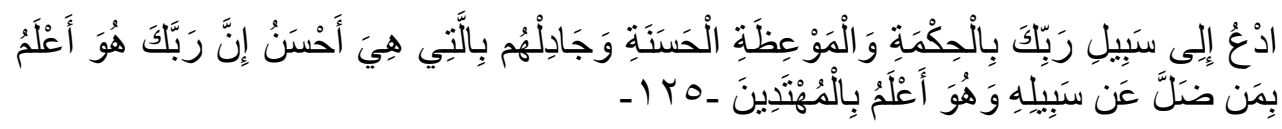

Serulah (manusia) kepada jalan Tuhanmu dengan hikmah dan pelajaran yang baik dan bantahlah mereka dengan cara yang baik. ${ }^{15}$

Sebenarnya, perintah untuk belajar dapat dilihat kembali dalam khitab Allah swt. tentang perintah ber-iqra' sebagaimana yang telah dikutip terdahulu, dan perintah untuk mengajar dapat pula dilihat kembali QS an-Nahl (16): 78 yang juga telah dikutip. Sedangkan dalam praktiknya, dapat disimak kembali dalam QS Luqman (31): 12-19 yang juga telah dikutip dalam uraian lalu. Pada hakikatnya, ayat-ayat tersebut berkenaan dengan kewajiban belajar dan mengajar melalui proses pendidikan.

Khusus untuk QS an-Nahl (16): 1245 di atas, adalah berkenaan dengan kewajiban belajar dan pembelajaran serta metodenya. Dalam ayat ini, Allah swt. menyuruh dalam arti mewajibkan kepada Nabi Muhammad saw. dan umatnya untuk belajar dan mengajar dengan menggunakan metode pembelajaran yang baik (hiya ahsan). Dari ayat ini, dapat dikolerasikan dengan metode belajar dan pembelajaran berdasarkan konsep qur'ani.

\section{METODE ALQURAN DALAM BELAJAR DAN PEMBELAJARAN}

Metode adalah al-manhaj atau al-wasilah, yakni sistem atau pendekatan serta sarana yang digunakan untuk mengantar kepada suatu tujuan. Dalam QS al-Maidah (5): 35 Allah swt., berfirman:

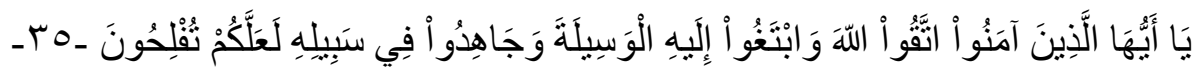

... dan carilah metode/sarana yang menekatkan diri pada-Nya dan berjihadlah pada jalan-Nya, supaya kamu mendapat keberuntungan.

Implikasi dari ayat di atas dan kaitannya dengna belajar dan pembelajaran bermuara pada pentingnya penggunaan metode menghantarkan tercapainya tujuan pendidikan yang islami sebagaimana yang dicita-citakan. Sehubungan dengan hal ini, penulis akan menjelaskan metode-metode Alquran serta belajar dan pembelajaran, sebagai berikut: 


\section{Metode Dialog/Diskusi}

Metode diskusi ${ }^{16}$ dapat diartikan sebagai jalan untuk memecahkan suatu permasalahan yang memerlukan beberapa jawaban alternatif yang dapat mendekati kebenaran dalam proses belajar dan pembelajaran akan dapat merangsang peserta didik untuk berfikir sistimatis, kritis dan bersikap demokratis dalam menyumbangkan pikiran-pikirannya dalam menyelesaikan sebuah masalah. Metode ini memberikan keleluasan dan keberanian kepada peserta didik untuk mengemukakan pendapatnya. Metode ini disebut pula metode hiwar yang meliputi dialog khitabi (bertanya dan lalu menjawab); dialog deskriptif dan dialog naratif (menggambarkan dan lalu mencermati); dialog argumentatif (berdiskusi lalu mengemukakan alasan kuat);

\section{Metode Kisah}

Metode kisah disebut pula metode kisah yakni cara mendidik dengan mengandalkan bahasa, baik lisan maupun tertulis dengan menyampaikan pesan (message/ informasi) dari sumber pokok sejarah Islam, yakni Alquran dan hadis. ${ }^{17}$ Salah satu metode yang digunakan Alquran untuk mengarahkan manusia (peserta didik) ke arah yang dikehendakinya adalah dengan menggunakan cerita (kisah). Misalnya saja, kisah nabi-nabi disebutkan dalam Alquran untuk memberikan kekuatan psikologis kepada peserta didik, dalam artian bahwa; dengan mengemukakan kisah-kisah nabi (nabawi) kepada peserta didik, mereka secara psikologis terdorong untuk menghadirkan kisah para nabi tersebut sebagai uswah (suri tauladan).

\section{Metode Perumpamaan}

Metode ini disebut metode amstal, 18 yakni cara mendidik dengan memberikan perumpamaan, sehingga mudah memahami suatu konsep. Perumpamaan yang diungkapkan Alquran memiliki tujuan psikologi edukatif, yang ditunjukkan oleh kedalam makna dan ketinggian maksudnya. Dampak edukatif dari perumpamaan Alquran diantaranya adalah; mempengaruhi emosi yang sejalan dengan konsep yang diumpamakan; mampu menciptakan motivasi yang menggerakkan aspek emosi dan mental peserta didik.

\section{Metode Keteladanan}

Metode ini disebut pula metode "meniru" yakni suatu metode pendidikan dan pengajaran dengan cara pendidik memberikan contoh teladan yang baik kepada peserta didik. Dalam Alquran, kata teladan diproyeksikan dengan kata uswah $^{19}$ yang kemudian diberi sifat di belakangnya seperti sifat hasanah yang berarti teladan yang baik. Metode keteladanan adalah suatu metode pembelajaran dengan cara pendidik memberikan contoh teladan yang baik kepada peserta didik agar ditiru dan dilaksanakan.

\section{Metode Praktik dan Pengulangan}

Metode ini, disebut pula metode praktek dan pengulangan yakni suatu metode pendidikan dan pembelajaran dengan cara pendidik memberikan ulangan. ${ }^{20}$ Misal- 
nya, latihan praktik salat dan atau dalam bentuk final semester. Untuk menguasai suatu materi pendididkan secara praktis diperlukan latihan-latihan teratur dan berulangulang. Dengan latihan teratur, maka pengetahuan dan keterampilan tertentu tidak saja dapat dikuasai secara sempurna tetapi juga selalu siap untuk dipergunakan.

\section{Metode Ibrah dan Mau'izhah}

Metode ini disebut pula metode nasihat ${ }^{21}$ yakni suatu metode pembelajaran dengan cara pendidik memberikan motivasi. Metode ibrah dan atau mau'izhah (nasihat) sangat efektif dalam pembentukan keimanan, mempersiapakan moral, spiritual dan sosial peserta didik. Nasihat dapat membukakan mata peserta didik terhadap hakekat sesuatu, serta memotivasinya untuk bersikap luhur, berakhlak mulia dan membekalinya dengan prinsip-prinsip Islam.

\section{Metode Targhib dan Tarhib}

Istilah targib dan tarhib22 dalam Alquran berarti ancaman atau intimidasi melalui hukuman yang disebabkan oleh suatu dosa kepada Allah dan Rasul-Nya. Jadi, ia juga dapat diartikan sebagai ancaman Allah melalui penonjolan salah satu sifat keagungan dan kekuatan Ilahiah agar peserta didik teringat untuk tidak melakukan kesalahan. Metode ini telah digunakan oleh masyarakat secara luas, orang tua terhadap anaknya, pendidik terhadap peserta didik. Bahkan Alquran ketika menggambarkan surga dengan kenikmatannya dan neraka dengan segala siksanya menggunakan metode ini. ${ }^{23}$

\section{SIMPULAN}

Berdasarkan pada uraian di atas maka dapat disimpulkan bahwa yang dimaksud belajar dan pembelajaran menurut petunjuk Alquran adalah aturan dalam proses kegiatan belajar dan pembelajaran berdasarkan dalil-dalil yang mengacu pada interpretasi ayat-ayat Alquran. Dalil-dalil yang berkenaan dengan ini adalah QS al-Alaq (96): 1-5 yang berbicara tentang perintah belaajar dan pembelajaran; QS al-Nahl (16): 78 yang berbicara tentang komponen pada diri manusia yang harus difungsikan dalam kegiatan belajar dan pembelajaran; QS Luqman (31): 17-19 yang berbicara tentang pemantapan aqidah dan akhlak dalam kegiatan belajar dan pembelajaran; QS al-Nahl (16): 125 dan selainnya yang kewajiban belajar dan pembelajaran serta metodemetode yang digunakan.

Sebagai pembelajar (pendidik) diharapkan dapat mengetahui dan memahami Alquran dan metodenya dalam proses belajar dan pembelajaran untuk memudahkan menguasai materi pembelajaran dan dengan sendirinya dapat mewujudkan tujuan pembelajaraan secara maksimal.

\section{CATATAN AKHIR}

1. Lihat QS Al-Isra'/17: 70

2. Lihat QS Al-Ahzab/33: 72 
3. Salam, B, Filsafat Manusia: Antropology Metafisiska (Cet. II; Jakarta: Bina Aksara, 1988), h.1.

4. Lihat Jusuf Amir Feisal, Reorientasi Pendidikan Islam (Cet. I; Jakarta: Gema Insani Press, 1995), h. 116-117

5. Alquran dan hadis sebagai landasan pendidikan Islam, dapat dikembangkan dengan ijtihad, almaslahah al-mursalah, istihsan, qiyas, dan sebagainya. Lihat Zakiah Darajat, et all. Ilmu Pendidikan Islam (Cet. III; Jakarta: Bumi Aksara, 1996), h. 19.

6. Sudirman AM, Interaksi dan Motivasi Belajar Mengajar (Cet. VII; Jakarta: PT. Raja Grafindo Persada, 2000), h. 53.

7. Lihat Maksum, Madrasah Sejarah dan Perkembangannya (Cet. I; Jakarta: Logos Wacana Ilmu, 1999), h. 54.

8. Departemen Agama RI, Al-Qur'an dan Terjemahnya (Jakarta: Proyek Penggandaan Kitab Suci alQur'an, 1992), h. 1079.

9. M. Quraish Shihab, Tafsir al-Qur'an al-Karim; Tafsir Surat-surat Pendek Berdasarkan Urutan Turunnya Wahyu (Bandung: Pustaka Hidaya, 1997). h. 93

10. Departemen Agama RI, Al-Qur'an dan Terjemahnya, h. 413.

11. Dawan Rahardjo, Ensiklopedi Alquran; Tafsir Sosial Berdasarkan Konsep-konsep Kunci (Jakarta: Paramadina, 1996), h. 542.

12. Departemen Agama RI, Al-Qur'an dan Terjemahnya, h. 413.

13. Luqman dalam mengajr shalat kepada anaknya, dimulai dengan panggilan yang mesra: wahai anakku sayang, laksanakan shalat dengan sempurna syarat, rukun, dan sunnah-sunnahnya, dan disamping engkau memperhatikan dirimu dan membentenginya dari kekejian dan kemungkaran, anjurkan pula orang lain berlaku serupa. Karena itu, perintahkanlah secara baik-baik siapa pun yang mampu engkau ajak mengerjakan ma'ruf dan cegahlah mereka dari kemungkaran. Tingkatkan kesabaranmu, karena sangat baik bagimu.

14. Lihat Umar Muhammad al-Taumiy al-Syaibani, Falsafah al-Tarbiyah al-Islamiyah diterjemahkan oleh Hasan Langgulung dengan judul: Falsafah Pendididkan Islam (Cet. I; Jakarta: Bulan Bintang, 1979), h. 416.

15. Departemen Agama RI, Al-Qur'an dan Terjemahnya, h. 412.

16. Kata diskusi berasal dari bahasa latin yaitu "discussus" berarti berpisah. Secara etimologi diskusi adalah suatu proses yang melibatkan dua individu atau lebih berintegrasi secara verbal dan saling berhadapan, saling tukar informasi, saling mempertahankan pendapat dalam memecahkan sebuah masalah tertentu. Lihat Ramayulis, Metodologi Pengajaran Agama Islam, (Jakarta: Kalam Mulia, 1990), h. 127.

17. Armain Arief, Pengantar Ilmu dan Metodologi Pendidikan Islam (Jakarta: Ciputat Pers, 2002), h. 160.

18. M. Arifin, Ilmu Pendidikan Islam Suatu Tinjauan Teoritis dan Praktis Berdasarkan Tinjauan Interdisipliner (Jakarta: Bumi Aksara, 2000), h. 77.

19. Kata uswah dalam Alquran dapat dilihat pada QS al-Mumthahanah (60): 4-6, QS al-Ahzab: (33): 21.

20. Armai Arief, Pengantar Ilmu dan Metodologi Pendidikan Islam, h. 174.

21. Nasehat adalah penjelasan kebenaran dan kemaslahatan dengan tujuan menghindarkan orang yang dinasehati dari bahaya serta menunjukkannya kejalan yang mendatangkan kebahagiaan dan manfaat. Lihat Abdurrahman al-Nahlawi, Ushul al-Tarbiyah al-Islamiyah wa Asalbuha fi al-Bayt wa al-Madrasah wa al-Mujtama' (Damaskus: Daar al-Fikr, 1979), h. 184-264.

22. Hery Noer Aly, Ilmu Pendidikan Islam (Ciputat: Logos Wacana Ilmu, 1999), h. 196.

23. Lihat QS al-Zalzalah (99): 6-8. 


\section{DAFTAR PUSTAKA}

Arief, Armai. Pengantar Ilmu dan Metodologi Pendidikan Islam. Jakarta: Ciputat Pers, 2002.

Arifin, M. Ilmu Pendidikan Islam Suatu Tinjauan Teoritis dan Praktis Berdasarkan Tinjauan Interdisipliner. Jakarta: Bumi Aksara, 2000.

AM, Sudirman. Interaksi dan Motivasi Belajar Mengajar, Cet. VII; Jakarta: PT. Raja Grafindo Persada, 2000.

Al-Taumiy al-Syaibani, Umar Muhammad. Falsafah al-Tarbiyah al-Islamiyah diterjemahkan oleh Hasan Langgulung dengan judul: Falsafah Pendidikan Islam, Cet I; Jakarta: Bulan Bintang, 1979.

B, Salam. Falsafah Manusia: Antropologi Metafisika, Cet. II; Jakarta: Bina Aksara, 1988.

Daradjat, Zakiah. Ilmu Pendidikan Islam, Cet. III; Jakarta: Bumi Aksara kerjasama dengan Depag, 1996.

Departemen Pendidikan dan Kebudayaan. Kamus Besar Bahasa Indonesia, Edisi III Cet. II; Jakarta: Balai Pustaka, 2002.

Departemen Agama RI. Alquran dan Terjemahnya. Jakarta: Proyek Pengadaan Kitab Suci Alqur'an, 1992.

Feisal, Jusuf Amir. Reorientasi Pendidikan Islam, Cet. I; Jakarta: Gema Insani Press, 1995.

al-Nahlawi, Abdurrahman. Ushul al-Tarbiyah al-Islamiyah wa asalbuha fi al-Bayt wa alMadrasah wa al-Mujtama'. Damascus: Daar al-Fikr, 1979.

Noer Aly, Hery. Ilmu Pendidikan Islam. Ciputat: Logos Wacana Ilmu, 1999.

Rahardjo, Dawan. Ensiklopedia Alquran, Tafsir Sosial Berdasarkan Konsep-Konsep Kunci. Jakarta: Paramadina, 1996.

Ramayulis. Metodologi Pengajaran Agama Islam. Jakarta: Kalam Mulia, 1990.

Shihab. H. M, Quraish. Tafsir al-Qur'an al-Kalam: Tafsir Surah-surah Pendek Berdasarkan Urutan Turunnya Wahyu. Bandung: Pustaka Hidaya, 1997.

Tirtahardja, Umar dan La Sula. Pengantar Pendidikan, Cet. I; Jakarta: Rineka Cipta, 1998. 